\title{
Pengaruh Jarak Tanam Yang Berbeda Terhadap Pertumbuhan dan Produksi Kelapa Sawit (Elaeis guineensis Jacq)
}

\author{
${ }^{* 1}$ Hayata ${ }^{1}$ Ida Nursanti dan ${ }^{2}$ Pandu Kriswibowo \\ ${ }^{1}$ Prodi Agroteknologi, Fakultas Pertanian Universitas Batanghari \\ ${ }^{2}$ Alumni Prodi Agroteknologi, Fakultas Pertanian Universitas Batanghari \\ Jl. Slamet Riyadi, Broni Jambi, 36122. Telp. +62741 60103 \\ ${ }^{* 1}$ e-mail korespondensi : hayatahayata82@gmail.com
}

\begin{abstract}
Plant distance is a factor influencing the growth of oil palm plants. Plant spacing is done to get an area for plant growth, to avoid a sun and nutrients competition for each oil palm plant, and to make it easier maintenance. This study aimed to see the growth and production of oil palm at different planting distances. This research was carried out at the oil palm smallholder plantation located in Suko Awinjaya Village, Sekernan District, Muaro Jambi Regeny, 64 kilometers (representing $8 \times 8 \mathrm{~m}$ spacing) and 69 kilometers (representing $9 \times 9 \mathrm{~m}$ spacing). This research was conducted in March-April 2019. The design of the experiment was carried out as an unformatted trial and the location was porpusively chosen as there were a uniform plants in that location. Sampling determination of the locations was based on spacing differences e.g. planting distance $8 \times 8 \mathrm{~m}$ (p1), planting distance $9 \times 9 \mathrm{~m}(\mathrm{p} 2)$. The systemic sampling method was used in this study. The parameters observed were plant height, stem circumference, weight of fresh fruit bunches (FFB), productivity, light intensity, air temperature, air humidity (\%). A measured agronomic each observed parameter was analyzed by independent t test (significant level of 5\%). The result showed that the oil palm plantations with $8 \times 8 \mathrm{~m}$ distance planted give a higher growth and a smaller stem circumference than the $9 \times 9 m$. While a higher both of fresh fruit bunch weight and productivity were obtained at a $9 \times 9 \mathrm{~m}$ spacing than those at $8 \times 8 \mathrm{~m}$ planted distance.
\end{abstract}

Keywords : Spacing, Productivity, Oil Palm

\begin{abstract}
Abstrak. Jarak tanam merupakan faktor yang mempengaruhi pertumbuhan tanaman kelapa sawit. Pengaturan jarak tanam bertujuan untuk mendapatkan ruang tumbuh bagi pertumbuhan tanaman guna menghindari kompetisi unsur hara dan cahaya matahari dari setiap tanaman kelapa sawit, serta mempermudah dalam pemeliharaan. Penelitian ini bertujuan untuk melihat pertumbuhan dan produksi kelapa sawit pada jarak tanam yang berbeda. Penelitian ini dilaksanakan di perkebunan kelapa sawit rakyat yang terletak di Desa Suko Awinjaya, Kecamatan Sekernan Kabupaten Muaro Jambi kilometer 64 (mewakili jarak tanam $8 \times 8 \mathrm{~m}$ ) dan kilometer 69 (mewakili jarak tanam 9×9 m). Penelitian ini dilakukan pada bulan Maret - April 2019. Penelitian dirancang secara tidak terformat dan lokasi dipilih secara sengaja karena pada lokasi tersebut terdapat tanaman yang seragam. Penentuan lokasi penelitian berdasarkan pada perbedaan jarak tanam yaitu: jarak tanam $8 \times 8 \mathrm{~m}$ (p1)dan jarak tanam 9×9 $\mathrm{m}$ (p2) Pengambilan sampel pada penelitian ini menggunakan metode sistemik sampling. Parameter yang diamati adalah tinggi tanaman, lingkar batang, berat tandan buah segar (TBS), produktivitas, intesitas cahaya, suhu udara, kelembaban udara (\%), dan tindakan agronomi. Setiap parameter yang diamati dianalisis dengan independent $\mathrm{t}$ test pada taraf $\alpha 5 \%$. Tanaman kelapa sawit yang ditanam pada jarak $8 \times 8 \mathrm{~m}$ memberikan hasil pertumbuhan yang lebih tinggi dan lingkar batang yang lebih kecil dibanding jarak tanam 9x9 m. Berat tandan buah segar dan produktivitas tanaman dengan jarak tanam 9x9 m lebih tinggi dibanding dengan tanaman yang ditanam pada jarak 8x8 m
\end{abstract}

Kata kunci : jarak tanam, produktivitas, kelapa sawit

\section{PENDAHULUAN}

Usaha budidaya kelapa sawit yang dilakukan tentulah mengharapkan produktivitas yang tinggi, karena itu bentuk pola tanam, jarak tanam dan kerapatan tanaman yang tepat akan memberikan dampak jangka panjang pada produktivitas kelapa sawit

Dalam melakukan penanam tanaman kelapa sawit hal yang pertama kali dilakukan adalah menentukan jarak tanaman kelapa sawit yang sesuai agar tidak mengganggu pertumbuhan dan produktifitas tanaman kelapa sawit itu sendiri dalam jangga waktu yang panjang.

Pengaturan jarak tanam sangat mendukung pertumbuhan tanaman dan produksi, karena jarak tanam berpengaruh terhadap kondisi iklim mikro disekitar tanaman dan penerimaan cahaya matahari. Jarak tanam yang rapat menyebabkan kelembaban udara yang tinggi di sekitar tanaman. Kondisi ini tidak menguntungkan untuk pertumbuhan tanaman karena tanaman mudah terserang penyakit (Cahyono, 2003). Jarak tanam yang tidak tepat 
akan menimbulkan pengaruh negatif dan beberapa kerugian kedepannya. Menurut Pima (2000) tanaman dengan jarak tanam yang normal akan mendapatkan cahaya matahari dan unsur hara yang cukup karena persaingan antar tanaman kelapa sawit lebih kecil sehingga mempengaruhi pertumbuhan dan produksi kelapa sawit.

Mengatur jarak antar tanaman merupakan bagian dari penyediaan tempat bagi tanaman. Bila ruang yang tersedia sempit, maka timbul persaingan dalam memperoleh unsur hara dan cahaya matahari. Pada tanaman tahuhan, tingkat persaingan ini selalu berubah seiring berubahnya umur tanaman. Oleh karna itu penentuan jarak tanam yang tepat untuk tanaman tahunan lebih sulit dibanding dengan tanaman semusim.(Wahyudi, 2008). Pada umumnya masalah-masalah atau gejala pada kerapatan tanam sebagai berikut: a) rendahnya intensitas cahaya matahari di dalam areal perkebunan; b) penurunan produksi tanaman kelapa sawit; c) pelepah saling menutupi dengan pokok batang yang bersebelahan; d) tegaknya pelepah akan menyebabkan terganggunya penyerbukan dan perkembangan tandan buah; e) keguguran buah sebelum matang pada pelepah bagian bawah; f) batang memanjang, tidak kokoh dan lebih kecil dari yang normal.

Jarak tanam yang terlalu rapat akan menimbulkan persaingan dalam memperoleh unsur hara, air, cahaya matahari, tempat untuk berkembang dan proses fotosintesis terganggu. Sebaliknya jika jarak tanam yang terlalu lebar tidak efisien dalam pemanfaatan lahan, dapat memperkecil populasi tanaman dalam satu hektar dan memperkecil hasil panen tanaman kelapa sawit. Jarak tanam yang terlalu lebar akan membuat penyinaran terhadap lahan lebih banyak sehingga dapat dimanfaatkan gulma untuk tumbuh, akibat terjadi persaingan antara gulma dengan tanaman pokok. Jarak tanaman tidak hanya mempengaruhi habitus tanaman dan luas perakaran, tetapi juga faktor-faktor lainya yang dapat mengakibatkan turunnya produktivitas tanaman kelapa sawit sehingga dapat merugikan petani (Susanto, 1994).

Usaha budidaya kelapa sawit di perkebunan rakyat di Kabupaten Muaro Jambi pada jenis tanaman yang sama menerapkan dua bentuk jarak tanam yaitu $8 \times 8 \mathrm{~m}$ dan $9 \times 9 \mathrm{~m}$. Jarak antar tanaman yang lebih rapat supaya mendapatkan populasi yang lebih banyak dengan harapan meningkatkan produksi dan produktivitas.

Penelitian ini bertujuan untuk melihat pertumbuhan dan produksi kelapa sawit pada jarak tanam yang berbeda.

\section{METODE PENELITIAN}

Penelitian ini dilaksanakan di kebun kelapa sawit rakyat yang terletak di Desa Suko Awinjaya, Sekernan Muaro Jambi kilometer 64 (mewakili jarak tanam $8 \times 8 \mathrm{~m}$ ) dan kilometer 69 (mewakili jarak tanam 9×9 m). Penelitian ini dilakukan pada bulan Maret sampai April 2019.

\section{Alat dan Bahan}

Alat yang digunakan pada penelitian ini adalah meteran, lux meter, kamera, GPS (Global Positioning System), timbangan sawit, Thermohigrometer dan alat tulis. Bahan yang digunakan meliputi tanaman kelapa sawit jenis Sriwijaya Sampurna Agro berumur 11 - 12 tahun yang seragam dengan jarak tanam 8×8 m dan 9×9 m.

\section{Rancangan Percobaan}

Percobaan dirancang secara tidak terformat dan lokasi dipilih secara sengaja karena pada lokasi tersebut terdapat tanaman yang diteliti dan seragam. Penelitian dilakukan pada perkebunan dengan jarak tanam yang berbeda, yaitu: jarak tanam $8 \times 8 \mathrm{~m}(\mathrm{p} 1)$ dan jarak tanam $9 \times 9 \mathrm{~m}(\mathrm{p} 2)$

Pengambilan sampel pada penelitian ini menggunakan metode sistemik sampling, masing-masing jarak tanam ditentukan populasi tanaman dalam $1 \mathrm{Ha}$, kemudian ditentukan populasi yang diambil sebanyak 100 batang populasi tanaman. Selanjutnya ditentukan tanaman sampel sebanyak $15 \%$ menggunakan perhitungan K yaitu : $K=$ $\frac{N}{n} . \quad K=100 / 15=6,67$ (dibulatkan 7). Siapkan kartu lotre sebanyak sembilan yang diberi nomor 1 sampai 9 kemudian diacak. Bila angka pertama yang keluar adalah 3 maka pengambilan sempel dimulai dari pohon nomor 3 , sampel ke dua ditambahkan 7 yaitu pohon nomor 10, begitu seterusnya sebanyak 15 tanaman sampel. Lokasi tanaman yang dijadikan sempel dicatat titik koordinat menggunakan GPS.

\section{Penentuan Lokasi Penelitian}

Lokasi survei di Desa Suko Awinjaya Kecamatan Sekernan Kabupaten Muaro Jambi, karena pada lokasi tersebut terdapat dua bentuk jarak tanam yaitu $8 \times 8 \mathrm{~m}$ dengan titik koordinat $\mathrm{LS}=01^{\circ} 16^{\prime} 02.35^{\prime \prime}, \mathrm{BT}=103^{\circ} 17^{\prime} 56.18^{\prime \prime}$, dan jarak tanam $9 \times 9 \mathrm{~m}$ dengan titik koordinat $\mathrm{LS}=01^{\circ} 20^{\prime} 17.38^{\prime \prime}, \mathrm{BT}=103^{\circ} 15^{\prime} 59.95^{\prime \prime}$. Tanaman kelapa sawit berumur 11-12 tahun

Parameter yang diamati, yaitu : tinggi tanaman (m), lingkar batang (m), berat tandan buah segar (TBS) (kg), produktivitas (ton ha $\left.{ }^{-1} \operatorname{tahun}^{-1}\right)$, intesitas cahaya (kaki lilin), suhu dan kelembaban udara $\left({ }^{\circ} \mathrm{C}\right.$ dan $\%$ ). 
Hayata, Ida Nursanti, dan Pandu Kris Wibowo. Pengaruh Jarak Tanam Yang Berbeda Terhadap Pertumbuhan dan Produksi Kelapa Sawit (Elaeis guineensis Jacq)

\section{Tindakan Agronomi} lapangan.

Utuk mengetahui tindakan agronomi yang dilakukan oleh petani di lapangan dengan cara wawancara di

\section{Analisis Data}

Untuk mengetahui perbedaan antara jarak tanam yang digunakan, setiap parameter yang diamati dilakukan analisis statistika menggunakan independent $t$ test pada taraf $\alpha 5 \%$.

\section{Tinggi Tanaman dan Lingkar Batang}

\section{HASIL DAN PEMBAHASAN}

Data hasil pengamatan di lapangan dan dilanjutkan dengan uji independent $t$ test menunjukkan tinggi tanaman dan lingkar batang berbeda nyata antara jarak tanam $8 \times 8 \mathrm{~m}(\mathrm{p} 1)$ dengan $9 \times 9 \mathrm{~m}(\mathrm{p} 2)$

Tabel 1. Rata-Rata Tinggi Tanaman dan Lingkar Batang Tanaman Kelapa sawit pada Jarak Tanam yang Berbeda.

\begin{tabular}{ccccc}
\hline Jarak Tanam & Tinggi Tanaman $(\mathrm{m})$ & $p$ & Lingkar Batang $(\mathrm{m})$ & $p$ \\
\hline $8 \times 8 \mathrm{~m}(\mathrm{p} 1)$ & 5,76 & 0,004 & 3,09 & 0,000 \\
$9 \times 9 \mathrm{~m}(\mathrm{p} 2)$ & 5,44 & & 3,49 & \\
\hline
\end{tabular}

Keterangan : Berbeda nyata pada $p<0,05$.

Tinggi tanaman kelapa sawit pada jarak tanam $8 \times 8 \mathrm{~m}$ yaitu $5,76 \mathrm{~m}$, hasil ini berbeda nyata bila dibanding dengan tinggi tanaman jarak tanam 9x9 m yaitu 5,44 m. Lebih tingginya tanaman pada jarak tanam $8 \times 8 \mathrm{~m}$ ini disebabkan karena pada jarak tersebut pelepah daun banyak saling bertautan antara satu pohon dengan pohon tanaman yang lainnya, sehingga terjadi kompetisi dalam memperoleh cahaya matahari, akibatnya terjadi perangsangan pertumbuhan meninggi lebih yang cepat dibanding pertumbuhan lingkar batang.

Jarak tanam merupakan faktor yang mempengaruhi pertumbuhan tanaman kelapa sawit, karena penyerapan energi matahari oleh permukaan daun sangat menentukan pertumbuhan tanaman. Semakin rapat populasi tanaman sawit dalam satu hektar maka akan sedikit jumlah intensitas cahaya matahari yang diperoleh oleh tanaman dan semakin tinggi tingkat kompetisi antar tanaman dalam untuk mendapatkan sinar matahari. Pada populasi yang lebih tinggi, kontak antar akar tanaman lebih cepat terjadi sehingga kompetisi dalam mendapatkan air dan unsur hara akan meningkat pada musim kemarau. Peningkatan jarak tanam sampai tingkat tertentu, dapat meningkatkan hasil per satuan luas sedangkan hasil tiap tanaman kelapa sawit akan menurun (Budiastuti, 2000).

Lingkar batang tanaman sawit pada jarak tanam 9x9 m yaitu sebesar 3,49, lebih besar dan berbeda nyata dibanding lingkar batang pada jarak tanam $8 \times 8 \mathrm{~m}$ yaitu 3,09 m. Besarnya lingkar batang pada jarak tanam 9x9 m, menunjukkan bahwa pada jarak tanam tersebut memungkinkan tanaman mendapatkan cahaya matahari yang cukup dan akar tidak berkompetisi memperoleh unsur hara. Tersedianya cahaya matahari serta unsur hara yang cukup akan membantu terjadinya proses fotosintesis secara maksimal, sehingga fotosintat yang dihasilkan dapat digunakan untuk membentuk pertumbuhan membesar batang.

Pada kerapatan jarak tanam yang tinggi, tingkat kompetisi diantara tanaman terhadap cahaya, air dan unsur hara semakin ketat sehingga tanaman kelapa sawit dapat terhambat pertumbuhannya (Hidayat, 2008).

\section{Berat Tandan Buah Segar (TBS) dan Produktivitas (ton ha' tahun $^{-1}$ )}

Data hasil pengamatan lapangan dan dilanjutkan dengan uji independent $t$ test menunjukkan bahwa berat tandan buah segar (TBS) dan produktivitas berbeda nyata antara jarak tanam $8 \times 8 \mathrm{~m}(\mathrm{p} 1)$ dengan $9 \times 9 \mathrm{~m}(\mathrm{p} 2)$.

Tabel 2. Rata-Rata Berat Tandan Buah Segar (TBS) dan Produktivitas pada Jarak Tanam Yang Berbeda.

\begin{tabular}{ccccc}
\hline Jarak Tanam & Berat TBS $(\mathrm{kg})$ & $p$ & Produktivitas TBS $\left(\right.$ ton $\mathrm{ha}^{-1}$ tahun $\left.^{-1}\right)$ & $p$ \\
\hline $8 \times 8 \mathrm{~m}(\mathrm{p} 1)$ & 8,46 & 0,000 & 21,18 & 0,000 \\
$9 \times 9 \mathrm{~m}(\mathrm{p} 2)$ & 10,82 & & 26,93 & \\
\hline
\end{tabular}

Keterangan : Berbeda nyata pada $\mathrm{p}<0,05$

Berat tandan buah segar (TBS) tanaman dengan jarak tanam 9 × 9 adalah 10,82 kg, dengan produktivitas sebesar 26,93 ton ha ${ }^{-1}$ tahun $^{-1}$, hasil ini berbeda nyata dibanding berat tandan buah segar dengan jarak tanam $8 \times 8 \mathrm{~m}$ yaitu $8,46 \mathrm{~kg}$ dan produktivitasnya 21,18 ton $\mathrm{ha}^{-1}$ tahun $^{-1}$. Lebih tingginya berat tandan buah dan produktivitas tanaman dengan jarak tanam $9 \times 9 \mathrm{~m}$, hal ini karena pada jarak tanam yang lebih lebar tidak terjadi persaingan antar tanaman dalam memperoleh unsur hara dan air di dalam tanah dan cahaya matahari, sehingga proses fotosintesis lebih optimum, energi untuk pertumbuhan vegetatif dan generatif tersedia, sehingga jumlah dan bobot buah yang lebih berat. Hal ini sejalan dengan pendapat Karo-Karo, dkk (2015) dalam Nur, Asrul dan Rafiuddin (2018), bahwa jarak tanam akan berpengaruh terhadap produksi tanaman karena berkaitan dengan ketersediaan unsur hara, cahaya 
matahari serta ruang bagi tanaman. Jika terjadi kompetisi pada tanaman maka pertumbuhan vegetatif dan generatif terganggu dan mengakibatkan hasil seperti ukuran biji kecil sehingga bobot biji jadi berkurang.

\section{Intesitas Cahaya (Kaki Lilin)}

Data hasil pengamatan lapangan dilanjutkan dengan uji independent t test, intensitas cahaya matahari berbeda nyata antara lokasi dengan jarak tanam $8 \times 8 \mathrm{~m}(\mathrm{p} 1)$ dengan jarak tanam $9 \times 9 \mathrm{~m}(\mathrm{p} 2)$.

Tabel 3. Rata-rata Intensitas Cahaya Matahari pada Lokasi Jarak Tanam yang Berbeda.

\begin{tabular}{ccc}
\hline Jarak tanam & Intensitas Cahaya (kaki lilin) & $p$ \\
\hline $8 \times 8 \mathrm{~m}(\mathrm{p} 1)$ & 459 & 0,003 \\
$9 \times 9 \mathrm{~m}(\mathrm{p} 2)$ & 641 & \\
\hline
\end{tabular}

Keterangan : Berbeda nyata pada $p<0,05$

Intensitas cahaya matahari yang berada di bawah kanopi daun sawit pada jarak tanam 9x9 $\mathrm{m}$ yaitu sebesar 641 kaki lilin, lebih tinggi dibanding di bawah kanopi tanaman dengan jarak tanam 8x8 m, yaitu 459 kaki lilin. Besarnya intensitas cahaya matahari yang sampai ke bawah kanopi daun sawit pada jarak tanam 9x9 m, menunjukkan bahwa pada jarak tanam yang agak lebih renggang memungkinkan cahaya lebih banyak sampai ke bawah atau ke permukaan tanah.

\section{Suhu dan Kelembaban Udara $\left({ }^{\circ} \mathrm{C}\right.$ dan \%)}

Data hasil pengamatan lapangan dan dilanjutkan dengan uji independent $t$ test, menunjukkan bahwa suhu dan kelembaban udara berbeda nyata antara lokasi dengan jarak tanam $8 \times 8 \mathrm{~m}(\mathrm{p} 1)$ dengan $9 \times 9 \mathrm{~m}(\mathrm{p} 2)$.

Tabel 4. Rata-Rata Suhu dan Kelembaban Udara Pada Siang hari Pada Lokasi dengan Jarak Tanam Yang Berbeda.

\begin{tabular}{cccc}
\hline Jarak Tanam Peubah & Suhu $\left({ }^{\circ} \mathrm{C}\right)$ & Kelembaban & $p$ \\
\hline $8 \times 8 \mathrm{~m}(\mathrm{p} 1)$ & 29,14 & 69,66 & 0,003 \\
$9 \times 9 \mathrm{~m}(\mathrm{p} 2)$ & 30,49 & 65,75 & \\
\hline
\end{tabular}

Keterangan : Berbeda nyata pada $p<0,05$.

Rata-rata suhu udara siang hari yang berada pada areal di bawah kanopi kebun sawit dengan jarak tanam 9x9 m yaitu $30,49{ }^{\circ} \mathrm{C}$, lebih tinggi dibanding suhu udara di bawah kanopi dengan jarak tanam $8 \times 8 \mathrm{~m}$, yaitu $29,14{ }^{\circ} \mathrm{C}$, berbanding terbalik dengan kelembaban udara pada jarak tanam 8x8 m (69,66\%), lebih tinggi dibanding kelembaban udara dengan jarak tanam 9x9 m yaitu 65,75\%. Menurut Fauzi (2005), selain curah hujan dan sinar matahari, tanaman kelapa sawit membutuhkan suhu optimum sekitar $24-28^{\circ} \mathrm{C}$. Meskipun demikian tanaman kelapa sawit dapat tumbuh pada suhu terendah yaitu $18^{\circ} \mathrm{C}$ dan tertingi $32^{\circ} \mathrm{C}$. Beberapa faktor yang mempengaruhi suhu adalah lama penyinaran dan ketinggian tempat.

Kelembaban optimum yang dibutuhkan tanaman kelapa sawit adalah $80 \%$. Faktor-faktor yang mempegaruhi kelembapan adalah suhu, sinar matahari, lama penyinaran, curah hujan dan evapotranspirasi (Fauzi, 2005).

\section{Tindakan Agronomi}

Berdasarkan hasil wawancara langsung di lapangan, diketahui bahwa tidak terdapat perbedaan tindakan agronomi antara petani yang menerapkan jarak tanam $8 \times 8 \mathrm{~m}(\mathrm{p} 1)$ dengan petani yang menerapkan jarak tanam $9 \times 9$ $\mathrm{m}$ (p2). Tindakan agronomi yang dilakukan petani dapat dilihat pada tabel bawah ini.

Tabel 5. Tindakan Agronomi Petani Pada Jarak Tanam Yang Berdeda.

\begin{tabular}{|c|c|c|}
\hline Tindakan Agronomi & $\mathrm{p} 1(8 \times 8 \mathrm{~m})$ & p2 $(9 \times 9 m)$ \\
\hline Luas Areal (Ha) & 6 & 26 \\
\hline Jenis Tanaman & Sriwijaya Sampurna Agro & Sriwijaya Sampurna Agro \\
\hline Umur Tanaman (tahun) & $11-12$ & $11-12$ \\
\hline Jarak Tanam (m) & $8 \times 8$ & $9 \times 9$ \\
\hline Kendala Pemanenan & Hujan dan Jalan Rusak & Hujan \\
\hline Berapa Kali Pemanenan & 2 Bulan Sekali & 2 Bulan Sekali \\
\hline Berapa Kali Dalam 1 (Tahun) & Ya & Ya \\
\hline Pemupukan & 3 & 3 \\
\hline Berapa Produksi Dalam 1 Bulan & $1,5-2$ ton & $1,5-2,5$ ton \\
\hline Pengendalian Gulma & Ya & Ya \\
\hline Jenis Pupuk & KCL, Phonska, Dolomit & KCL, Phonska, Dolomit \\
\hline
\end{tabular}


Berdasarkan hasil wawancara di lapangan, diketahui tidak terdapat perbedaan umur tanaman antara $8 \times 8 \mathrm{~m}$ (p1) dan 9×9 m (p2) yaitu 11-12 tahun, menggunakan bibit kelapa sawit Sriwijaya Sampurna Agro. Untuk tindakan agonomi petani sama-sama melakukan pemupukan KCL, Phonska dan Dolomit pada lahan p1 dan p2, pengendalian gulma pada petani $\mathrm{p} 1$ dan $\mathrm{p} 2$ dilakukan dengan cara disemprot. Perbedaan pertumbuhan dan produksi kelapa sawit dalam hal ini lebih dipengaruhi oleh jarak tanam.

\section{KESIMPULAN}

Tanaman kelapa sawit yang ditanam dengan jarak 8x8 m menunjukkan pertumbuhan batang yang lebih tinggi dan lingkar batang yang lebih kecil dibanding tanaman yang ditanam dengan jarak tanam 9x9 $\mathrm{m}$. Berat tandan buah segar dan produktivitas tanaman yang ditanam dengan jarak tanam 9x9 $\mathrm{m}$ lebih tinggi dibanding tanaman kelapa sawit yang ditanam dengan jarak $8 \times 8 \mathrm{~m}$.

\section{DAFTAR PUSTAKA}

Budiastuti, MTh, S. 2000. Penggunaan Triakontanol dan Jarak Tanam PadaTanaman Kacang Hijau (Phaseolus radiatus L.). Agrosains Vol 2 (2) (2000). Universitas 11 Maret, Surakarta.

Cahyono, B. 2003. Teknik dan Strategi Budidaya Sawi Hijau (Pai-Tsai). Hal 12-62. Yogyakarta : Yayasan Pustaka Nusatama

Fauzi, 2005. Kelapa Sawit : Budidaya, Pemanfaatan dan hasil limbah. Analisis usaha dan Pemasaran. Penebar Swadaya. Jakarta.

Hidayat, 2008. Pertumbuhan dan Produksi Kacang Tanah (Arachis hypogea L) Verietas Lokal Pada Berbagai Jarak Tanam.

Nur, M., Asrul, Rafiuddin. 2018. Pengaruh Jarak Tanam Terhadap Pertumbuhan dan Hasil Jagung (Zea mays. L.) Pada Tingkat Umur Kelapa Sawit (Elais guinensis Jacq). Buletin Palma Vol. 19. No. 2. Tahun 2018 hal. 127-146

Pima, D. 2009. Pengaruh Sistem Jarak Tanam dan Metode Pengendalian Gulma Terhadap Pertumbuhan dan Produksi Jagung. (Zea mays L.) Varietas DK3

Susanto,1994. Tanaman Kakao Budidaya dan Pengolahan Pascapanen. Konisius. Yogyakarta. Hal : 74.

Wahyudi, dkk, 2008. Panduan Lengkap Kakao, Penebar Swadaya, Jakarta. 